\title{
International Monetary Fund Lending Effectiveness: Case of Albania
}

\section{Güngör Turan}

\author{
Phd in Economics, Department of Economics, Epoka University, Tirana; gturan@epoka.edu.al
}

\section{Klevis Qazimllari}

MSc student in Banking and Finance, Epoka University, Tirana; kqazimllari10@epoka.edu.al

\author{
Doi:10.5901/ajis.2015.v4n3s1p205
}

\section{Abstract}

The main aim of the paper is to analyze the effectiveness of IMF funds that Albania receives, and are they good sources to stimulate economic development, reduction of poverty, increase health and help environmental issues. In many countries IMF programs appear to be ineffective and also in Albania somehow, funds did not achieve to be the main source of development. But, it is not only IMF that makes the programs ineffective because very important factor in realization are official people working in corresponding countries, external shocks, policy changes and compatibility of programs with country public policies.

Keywords: IMF, effectiveness, development, Albania.

\section{Introduction}

Financial support for development is a phenomenon that became largely spread after World War II. In "Bretton Woods" conference in July 1994 nations were conceived that World needs a multilateral organization, whose focus will be to help economic development and progress of nation states in the whole world. International Monetary Fund (IMF) was formed in 1946 with 46 member states and today it has grown and includes 188 countries. The main proposes of the organization founded in the Article of Agreement of IMF in Article I are; promoting international monetarycooperation; expanding the balanced growth of international trade; facilitating exchange ratestability; eliminating restrictions on the international flow of capital; ensuring confidence bymaking the general resources of the Fund temporarily available to members; and adjustingbalance-of-payments imbalances in an orderly manner. World Bank (WB) is considered as sister organization as their operation framework is nearly same and together they do universal lending.

IMF has introduced reforms in its operation expanding its role not only providing short term loans and helping under developed and developing countries but also as a financial crises manager and helping hand. After Bretton Woods's system collapse in 1970 continued with the oil crises in that decade, world debt crises in 1980 and collapse of socialism have dropped down the original mission of IMF making it as the main actor to respond to crises and economic changes in the world. Lastly the fundamental mission published by IMF is to help ensure stability in the international system by; keeping track of the global economy and economies of member countries, lending to countries with balance of payments difficulties and giving practical help to members(IMF).

Republic of Albania became part of IMF on $5^{\text {th }}$ of October 1991. Based on the regulations and quota reforms that entered into force in 2008 the Albania's quota is 60 million, currently has $0.05 \%$ of the total votes of IMF members. Albania is in the same consistency with Italy, Greece, Portugal, Malta and San Marino. Albania since the end of communism in 1990s has had continual development in economic, social and environmental issues. But the political issues of 90s have left Albania's economy still under recovery; national debt, trade imbalances and dependence on monetary policies of European Union in order to become part of EU have left place for development. IMF has shown continual support for Albania, lastly in February 2014 IMF has approved 36 month fund from 330 million Euros under Extended-Fund Facility (EFF) for Albania in support of the authorities reform program. (IMF, 2014)

\section{Literature Review}

Based on the literature, effectiveness of IMF loans have been decreased lastly as the mission and overall aims have changed. In many countries in the world even though the continuous support of IMF still people are dying from hunger 
and environmental problems. The programs of IMF are criticized for many irregularities, transparency and moral hazard.

A study done by ODI (1993) if IMF funds are helping developing countries or not conclude that from evidences on programme effects their achievment is over rated. Funds generally secure sustained improvments but to not achieve growth and inflation controling. Eventhough some of the aspects of developing countries have been improved related to the sustained development of their environement, economy and politics still Fund is not capable to be the main actor of regulating the countries. OECD governments decide on Fund's policies and the way of implementation so a important burden of effectivness is related to developing countries policies and determination of usage of the fund.

Boockmann and Dreher (2002) have done a study on contrubution of IMF on economic freedom of countries in developing process. The results show that IMF programmes contribute less than World Bank in economic freedom, estimates taken into consideration are structural, growth oriented policies. This is closely related to the critics done for IMF that is demanding scale back the mandate of the Fund in order to restrain its activities to key areas of expertise, providing short term balance of payments credits and let World Bank deal with the development goals.

Eke and Kutan (2009) have made a very significant study for countries of East Europe testin the effectiveness of IMF programs and emphasising that they have failed to meet the main objectives of providing temporary asistance and only $21 \%$ of the programs in transition economies from 1990-2003 were completed successfully. Also the study have included the before-and-after analysis and again they showed to be ineffective. Authors in the paper have concluded that IMF proframs effectiveness or ineffectiveness is determined by the nature of the IMF programs and policies, the commitment of the country officials to implement the program, policy changes, and external shocks. So it is not IMF the main actor of failin or success.

A significant study done by Lamdany (2009) emphasizes the importance and effectiveness of structural conditionals of IMF programs. The study assesses that structural conditions are meant to lead policy reforms but from evidences from 1995-2004 for 17 programs only $5 \%$ of structural conditions called for lasting structural reforms and only one third of these were complied with. More than $40 \%$ of conditions called for preparing plans or drafting legislation. These low percentages of compliance with the conditions suggest that they are not properly playing its main role of safeguarding Fund resources. In the same time many of the conditions were criticized for intruding policymaking process and detracting from society's sense of ownership of the programs.

Another study related to effectiveness of IMF and World Bank funds was done for Sub-Saharan Africa countries by Wohlwend (2010), considering that the funds given to these countries are riddled with idealism, high expectations, disappointing results and subsequent cynical backlash. Even thougt the good intention of the organizations to help these countries they have not achieved the main objective of lowerng hunger and poverty.

From the literature review presented it can be concluded that IMF have lost its main mission and objectives that have been implemented in the beginning and the reason of existence from Bretton Woods Conference. Because of continual changes in the conditions of living, environment, social and political life IMF now has become an institution to give long term loans and preventer of the crises. Fund's effectiveness is still under the question mark for developing countries and even more for under developed African countries, those are taking huge amount of aid and still are under poverty and hunger.

\section{IMF Lending Effectiveness to Albania}

From the beginning of relation of IMF and Albania, country has taken in total 5 loans. Four of these loans were delivered in 2 or 3 divisions in order to have more control from IMF on the money landed and to use them more efficiently.

Based on the study done byODI (1993) the effectiveness of the programmes in practice is difficult to be meausred. Given in the study that empiricle research makes it possible to offer some generalisations about programme efects;

- Fund programmes usually strengthen the Balance of Payments

- Programmes usually break down before being fully completed

- Programmes do not have effect on inflation rate

- Programmes have a muted impact on economic growth

- There is little evidence that programmes typically impose large social costs, although the urban labor force commonly suffers reduced real earnings, and cuts in budget subsidiaries can have serious effects

- Programmes that break down do so because of adverse external developments

- Programmes often fail to trigger additional inflows of capital from the rest of the world, despite claims that Fund's seal of approval has a catalytic effect on capital inflows

- Programmes often do not have influence on fiscal and monetary policies 
- There has been a good deal of political interference in Fund lending decisions

Funds in all the developing countries that have been landed have been "noisy". Based on the criteria given above by Overseas Development Institute a relation of Albania's situation can be drawn up.

\begin{tabular}{|c|c|l|}
\hline Time Period of the Loan Approval & Amount of Loan/ in Dollars & Type of Loan \\
\hline Nov-97 & 12 Million & Credit \\
\hline May-98 & 59.9 Million & ESAF loan \\
\hline Jun-02 & 36 Million & PRGF 3 year loan ( 3 years, 6 reviews) \\
\hline Jan-06 & 24.7 Million & PRGF AND EFF ( 3 years, 6 reviews) \\
\hline Feb-14 & 457.1 Million & EFF fund \\
\hline
\end{tabular}

Source: IMF

\subsection{The First Loan in '97}

IMF in 1997 has approved the emergency post conflict assistance for Albania. This assistance was given as support for government to proceed with economic program for 1997-1998. In that time Albania was a country in transition from isolation and fighting with poverty. From years 1993 it has shown substantial progress having growth of $9 \%$, decreasing the inflation from triple digits to $6 \%$ and external imbalances were reduces etc. Than in 1997 because of election-driven policies budget deficit was raised, collapse pyramidal schemes and other management difficulties the whole Albania was near the economic and political collapse having a civil war. The program of recovery that Albanian government prepared was going to be helped by IMF. The government's primary macroeconomic goal, for 1997-98 were rapid disinflation and resumption of growth. The key macroeconomic objectives of the program were: (i) to limit the decline of real GDP to 8 percent in 1997 and achieve real growth of about 12 percent in 1998; (ii) contain the annual inflation rate to the range of 51-54 percent in 1997, and bring it down to 15- 20 percent in 1998; and (iii) keep gross international reserves above the equivalent of 3.5 months of imports through 1998.

The program of IMF contained structural reforms and addressing social needs. IMF was very positively looking up on Albania as it has experienced it before in 1993 to decrees rapidly the inflations, so also in 1997 the inflation could be reduced. In the end of this 6 months program the economy of Albania started to recover in those years, but it cannot be concluded that the main reason for this are IMF funding as the program was more managed by Albanian government.

\subsection{Second Loan in ' 98}

One year after the first loan immediately Albania was in need of being helped again, IMF in May 1998 approved a three year loan under the Enhanced Structural Adjustment Facility (ESAF) equivalent to 47 million dollars, in support for government in its economic program. Being referred from the country reports for Albania the new government that won the elections in mid-1997 adopted a two stage strategy. The first one that lead to macroeconomic stabilization and rebuilding of institutional and administrative capacity which was supported by IMF and the second stage was considered the one that was supported by ESAF program of IMF to help medium-term macroeconomic and structural program. The main aims of this strategy were to increase growth, reduce inflation, generate new job places and reduce poverty. The projection were to achieve 7-8\% growth, inflation 3\% and decrease the current deficit to about $6.5 \%$ of the total GDP in 1998. Also monetary policy in the short term should have some reforms, the Bank of Albania should have decreased at minimum deposit rates. However, there should be scope later in 1998 to lower nominal rates as inflation falls and pressure on the financial system to finance the budget deficit is reduced. This program was also in support of the foreign administrations of the firms in order to not allow the private sector to collapse, banking sector reforms were essential to increase the rule of law in this sector and also enterprise privatization, agriculture, public administration, lower corruption and remittances coming in from abroad were part of structural reforms which would help Albania in those years to recover its economy. IMF loan was used in all of these areas. The main challenge in the time of this loan was the security in the country and region which was lowering the interest of foreigners to invest and help economy to generate development. The second part of the loan was given in June, 1999 as the augmentation takes into account Albania's increased balance of payments needs arising from the impact of the Kosovo was. Prior to this Kosovo crisis, macroeconomic stability had been restored and economic trends were highly encouraging. This impact was not possible to be stopped so the only way was to take also help from abroad and other European countries. 
Based on the report of IMF (1999) for the performance of Albania under the adjutment strategy; country has achieved to have more stable macroeconomic situation in 1998.

\begin{tabular}{|c|c|}
\hline ADJ & SMENTS OF ALBANIAN ECONOMY \\
\hline 1. & Deficit was decresed to $6.5 \%$ of the GDP from 10.3\% that it was in 1997. \\
\hline 2. & Inflation declined to 8.7 percent in the year to December 1998, having peaked at 42 percent during 1997 \\
\hline 3. & $\begin{array}{l}\text { The restoration of law and order and of macroeconomic stability in } 1998 \text { underpinned a strong revival of growth, estimated at } 8 \\
\text { percent }\end{array}$ \\
\hline 4. & $\begin{array}{l}\text { Recovery in imports was less than expected, while inflows of private remittances recovered strongly, the current account deficit fell } \\
\text { to about } 6 \text { percent of GDP from } 12 \text { percent of GDP in } 1997\end{array}$ \\
\hline 5. & $\begin{array}{l}\text { Foreign administrators, who were appointed in 1997, sold some of the assets for which clear title is available, and have now turned } \\
\text { over to local administrators the task of disposing of the remaining assets and distributing the proceeds to investors }\end{array}$ \\
\hline & $\begin{array}{l}\text { The auditors' final report on the schemes was presented in April 1999. Moreover, parliament has passed legislation designed to } \\
\text { prevent a recurrence of the pyramid scheme phenomenon }\end{array}$ \\
\hline & $\begin{array}{l}\text { Banking System Law (drafted with assistance from the IMF and designed to prevent illegal activities and ensure that only financial } \\
\text { institutions can take deposits) was approved by parliament in June 1998, draft Money Laundering Law has been prepared by the } \\
\text { Bank of Albania, and the enforcement of the Companies Law and other commercial laws is being improved }\end{array}$ \\
\hline & $\begin{array}{l}\text { The reforms needed to sustain recovery have continued. To complement the cleanupof the informal financial sector, the government } \\
\text { has taken measures to restructure the state-owned banks: the Rural Commercial Bank was put into liquidation, the National } \\
\text { Commercial Bank (NCB) has been prepared for privatization and a foreign strategic buyer selected, and the Savings Bank is now } \\
\text { required to adhere to a governance contract which gives veto power in key operational decisions to foreign advisors }\end{array}$ \\
\hline 9. & 450 small- and medium-sized enterprises (SMEs) have been privatized since the beginning of 1998 \\
\hline & Agricultural land registration has proceeded at a brisk pace \\
\hline & Staffing in the civil service has been reduced with employment cuts of more than 10 percent since the \\
\hline
\end{tabular}

All this recoveries make this IMF loan efficient in the way it was distributed to different sectors in order to have the effect in the whole development of the country in not just in some specific sectors.

On November 22, 1999, the IMF's concessional facility for low-income countries, the Enhanced Structural Adjustment Facility (ESAF), was renamed the Poverty Reduction and Growth Facility (PRGF), and its purposes were redefined. It is intended that PRGF-supported programs will in time be based on country-owned poverty reduction strategies adopted in a participatory process involving civil society and development partners, and articulated in a poverty reduction strategy paper (PRSP). So also the lending of year 1998 was changes for Albania, as it was a program consisting 3 years and 3 review, from ESAF to PRGF. (IMF, 2000)

In every review, when the drawings of the money were being made IMF was indicating that Albania is having progress and is completing the projections, which makes the program to be effective and helpful. Despite this progress, in 2000 Albania still had the lowest level of per capita income in Europe and was in war with poverty. In consistence with the initiative under the Stability Pact, Albanian government prepared a Poverty Reduction Strategy Paper (PRSP) by mif2001 and launch a new national poverty reduction plan. The plan in order to be more effective and allocative was prepared in accordance with suggestions and participation of representatives of civil society, local communities, the poor and the donor community. Poverty in Albania in those years was high and it needed to be addressed and solved. In 1996 Albania based on the study done by Living Standard Measurement Survey (LSMS) indicated that the poverty is a problem of rural areas with $90 \%$ under poverty. Key elements in the program poverty reduction are;

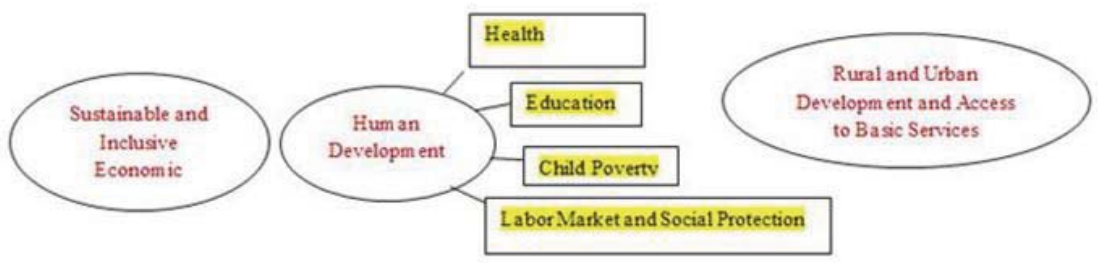

\subsection{Third Loan in '02}

In 2002 Executive Board of IMF approved another three year arrangement under PRGF loan in amount of 36 million dollars. This new PRGF program aimed to build on the progress made under the previous ones. The program in the first 
year was addressing Policies related to energy sector and recent problems in tax collection. Another important aim was achieving medium-term fiscal sustainability and sustaining high growth and ensuring a sustainable external position over the medium term which required wide range of reforms to improve the business climate and establish a fully functioning market economy. Crucial to this program were reforming the electricity sector, reconciling inter-enterprise, strengthening governance and the rule of law, and completing the privatization process. (IMF, 2002)

After three reviews and loans delivered the IMF Country report (2004) concluded that despite the political problems because of local election, majority party convention, government reshuffling, Albania again can be considered as a progress story related to macroeconomic indicators and structural reforms that have implemented.

\begin{tabular}{|c|c|}
\hline \multicolumn{2}{|c|}{ MACROECONOMIC PERFORMANCE UNDER THE PRGF (2002-2004) } \\
\hline Growth & $\begin{array}{l}\text { Growth has recovered to } 6.0 \% \text { thanks in large part of domestic demand, deposit increase, exports increase } \\
\text { (trade balance was improved by } 1.5 \% \text { of GDP). }\end{array}$ \\
\hline Inflation & $\begin{array}{l}\text { Mitigated substantially during } 2003,2.3 \% \text {. Investment Environment became more favorable because of lower } \\
\text { prices for repos between April and December 2003. Savings Bank was sold to Raiffesien Bank which improved } \\
\text { the overall panorama of banking sector. }\end{array}$ \\
\hline Fiscal Policy & $\begin{array}{l}\text { Fiscal Consolidation remained on track during } 2003 \text { and the targets for the deficit were met. Improvements in } \\
\text { tax administration, new excise tax low increased the tax revenues. Authoritiesa have set aside a contingency } \\
\text { expenditure plan so as to protect priority spending should unforeseen risks arise. }\end{array}$ \\
\hline $\begin{array}{l}\text { Structural Reforms and } \\
\text { basic infrastructure }\end{array}$ & $\begin{array}{l}\text { Two main long pending issues that were achieved; Savings Bank privatization and Power sector has shown } \\
\text { remarkable improvements. All targets in terms of the reduction of technical and financial losses have been met, } \\
\text { KESH financial situation has significantly improved, privatization and distribution system are under } \\
\text { consideration, privatization of INSIG, insurance company also started. Tirana-Durres-Rinas railway project also } \\
\text { started to be projected. }\end{array}$ \\
\hline External Relations & $\begin{array}{l}\text { Albania has shown improvement in the current account and had no difficulties in meeting external debt } \\
\text { obligations, Fund payment was on schedule also. Albania started to look for stimulating investment for } \\
\text { infrastructure, exploiting the geographical locations in EU. Government starting to use bilateral agreements and } \\
\text { technical assistance in the areas of institutional reform, financial and capital market and infrastructure } \\
\text { development. }\end{array}$ \\
\hline Governance & $\begin{array}{l}\text { Governance also has been strengthened. Good governance has always been critical in development of Albania } \\
\text { and to the strengthening of the private sector role in the economy, they have been looking forward to identifying } \\
\text { a better program framework in this respect so as to achieve more comprehensive results. This was one of the } \\
\text { main challenging tasks but the authorities has all the time been strongly committed to improve the performance, } \\
\text { in all the programs. }\end{array}$ \\
\hline
\end{tabular}

Source: IMF country reports

This results indicate that Albania has been improving these periods, which means that IMF has been helping this improvement even though the country itself was in transition and improvement was crucial.

\subsection{Forth Loan in '06}

In 2006 IMF approved three year arrangements under PRGF and EFF amounting to the equivalent 24.7 million dollars. This program supported by IMF was aiming to be the last Fund for Albania. The program focused on having financial policies, promoting reforms aimed at enhancing growth potential, strengthening government solvency, reducing vulnerabilities, protecting priority expenditure, and improving governance and the business climate. The main objectives were; real GDP to be $6 \%$ by 2007, inflation remain 3\% with (pulse/minus $1 \%$ ). Reforms in taxes, expenditures management would permit the quantity and quality of public investments to increase alongside, decline the debt, domestic borrowing gradually to be reduced. PRGF loans carry an annual interest rate of $0.5 \%$ and are payable over 10 years with 5.5 year grace period on principle payments.

The loan of EFF aims to support programs that seek to overcome balance of payments and difficulties stemming from macroeconomic imbalances and structural problems.

Based on the Country Report of IMF (2009) in the end of all the reviews of the loan in 2008, PRGF-EFF arrangements Albania has non-inflationary growth, which made Albania to pass to the rank list of middle income countries. Growth was continually over $6 \%$, while inflation was nearly $3 \%$.

Public finances were improved. Improvement were shown in; revenue administration, tax revenues to GDP ratio increased by over $2 \%$, improvements in public debt management have led to a reduction in the debt to GDP ratio from $56 \%$ in 2006 to $52.6 \%$ in 2008 and to the doubling of the average maturity of public debt, the deterioration in the current 
balance from $-7.3 \%$ in 2006 to -11.8 in 2008. Policy implementations in 2009 had been broadly in line with the program and authorities maintained tight macroeconomic policies which means that Albania has worked very efficiently on the program of IMF. All quantitative performance criteria and structural benchmarks were met. The only criteria not met is the one of the end of October for effective electricity collection rate for the electricity company KESH. In 2009 Albania was facing the adverse consequences with global economy. Albanian authorities have looked upon 2009 with the aim to preserve macroeconomic stability and reduce vulnerabilities and still improve structural reforms.

\begin{tabular}{|c|c|}
\hline Policy commitments for 2009 & $\begin{array}{l}\text { The authorities have worked for fiscal policy. In the face of less favorable financing conditions and } \\
\text { heightened rollover risk, they have tightened the } 2008 \text { budget. } 2008 \text { deficit target was } 5.2 \text { percent of } \\
\text { GDP. The } 2009 \text { budget envisages a deficit of below } 4 \text { percent of GDP. Against a background of } \\
\text { intensified financing pressures and uncertainty in early } 2009 \text {, the authorities agreed to further strengthen } \\
\text { the budget by increasing wholesale electricity tariffs, as well as by postponing the planned reductions in } \\
\text { the employer social security contribution rate from January to May. Moreover, the } 2009 \text { budget includes } \\
\text { contingency reserves of about } 2 \text { percent of GDP. Albania is using inflation target range with flexible } \\
\text { exchange rate regime. }\end{array}$ \\
\hline $\begin{array}{l}\text { Impact of the global financial } \\
\text { turmoil on the financial system }\end{array}$ & $\begin{array}{l}\text { Impact of the global financial turmoil on the financial system. In } 2008 \text { some bankswithdrawal of bank } \\
\text { deposit. Large liquidity buffers.Albania's financial system compares favorably within the region. Despite } \\
\text { those strengths, the authorities have had intensified efforts to improve crisis management in case of a } \\
\text { further worsening of financial conditions. }\end{array}$ \\
\hline Structural Reforms & $\begin{array}{l}\text { Further progress has been made in structural reform. The privatization program has properly worked by } \\
\text { coming to the end with the sale of the oil company ARMO and the insurance company } \\
\text { INSIG.Successfully electricity company KESH in June } 2007 \text {, a } 76 \% \text { stake in the power distribution } \\
\text { system operator OSSH took the tender, and final negotiations with the winning bidder started in } \\
\text { November } 2008 \text {. Efficiency of collection of electricity bills would be increased by } 82 \% \text { by } 2014 \text {. The } \\
\text { authorities remain committed to ensure complete cost recovery tariffs for KESH. }\end{array}$ \\
\hline Relationship with the Fund & Fund-supported programs have served as a policy anchor since the early 1990 s. \\
\hline
\end{tabular}

Source: IMF country reports

\subsection{Fifth Loan in '14}

Executive Board of IMF on February 28, 2014 approved 36 month loan in support of the authorities' reform program in value of 457.1 million dollar. EFF program in 2014 gave an outlook for Albanian economy by expecting improvements the whole 2014, reduction of risk in fiscal areas, clearance of arrears, tackling of high nonperforming loans and the launch of structural reforms. High public indebtedness needs fiscal consolidation which requires significant tax and expenditures policy measures, supported by extensive public financial management and tax administration reform, moderation of monetary policy, preserving financial stability while promoting access to credit necessary facilitates durable recovery. Authorities in 2014 planned to reform pensions system, energy, local government finances, public administration, business environment etc. Aiming to attract foreign direct investments and have sustainable growth.

In March 2015 a review was made by IMF, in order to have a view on have things are going in the reforms program of the government of Albania.

Concluding remarks of this review were; according to IMF, Albania's economic performance is on track, they have reached the agreement on future collaboration on forth review of the loan. Economic growth will be recovered during the 2015 in order to reach 3\% projections even though the slowdowns because of oil sector. Growth will be generated from domestic demand, energy prices, interest rates and bank landings. But, output is considered to be lower than the potential.

Fiscal policy is also on line with the targets, authorities remain committed to achieve the targets. Monetary policy should continuously support economy improvements and maintain price stability. Credit growth is recovering but is effected by non-performing loans and weaknesses in contract enforcement which leads to the conclusion that rule of law is low in Albania. Power sector reform implementation is on track, which is helped from World Bank. Electricity theft has been reduced, tariffs have been adjusted and revenues increased. All these indicators can lead us to the conclusion that Albania is on the good track of being improved and achieve to have reforms. 


\section{Conclusion}

Albania is not undeveloped country, the percentage of people dying from hunger and environmental problems are not as much as in African countries and other poor countries, so relating this fact with literature, which is concluding a decrease in effectiveness of the IMF loans, may not be true to Albania also. Based on country reports for Albania, country shows significant improvements but all these progress cannot be addressed only to IMF loans. Albania as a country in development is not whole dependent on IMF fund. It is generating profits from GDP, from bilateral agreements and groupcountries agreements and it has passed through transition and the growth is normal. The programs of IMF are criticized for many irregularities, transparency and moral hazard and this makes the reports to be under doubt sometimes.

But based on the country reports and overall economic, political and social performance of Albania, improvements has been observed in many in sectors that IMF fund money was used. It can be concluded that funds has been used in proper and efficient way and have generated progress and improvement in overall picture of Albania.

In general, it can be concluded that IMF loans can be considered as a driving force toward improvement and enhancement of Albanian economic and political situation.

\section{References}

Boockmann, B., \& Dreher, A. (2002). The contribution of the IMF and the World Bank to economic freedom. Centre for European Economic Research .

Eke, B., \& Kutan, A. M. (2009). Are international Monetary Fund Programs Effective? Evidence from East European Countries. Eastern European Economics, Vol. 47, No.1, 5-28.

IMF. (2002). IMF Approves In Principle 3-year, US\$36 Million PRGF Loan to Albania. IMF.

IMF. (n.d.). IMF . Retrieved May 2015, from http://www.imf.org.

IMF. (2006). Country Report. IMF.

IMF. (2009). Country Report. IMF.

IMF. (2015). Statement at the Conclusion of an IMF Mission to Albania.IMF

IMF\&WB Staff. (1999). Enhanced Structural Adjustment Facility Policy Framework Paper for 1999-2001 . IMF.

ODI, O. D. (1993). Does the IMF really help developing countries? . Overseas Developing Institute.

Wohlwend, D. A. (2010). Considering the International Monetary Fund and World Bank: Lending Effectiveness in Sub-Saharan Africa. Topical Review Digest: Human Rights in Sub-Saharan Africa. 